\title{
The effects of protein dietary supplementation on fecal egg counts and hematological parameters in goat kids with subclinical nematodosis
}

\author{
Priyanka Konwar, S. P. Tiwari, M. Gohain and Kiran Kumari \\ Department of Animal Nutrition, College of Veterinary Science and Animal Husbandry, \\ Chhattisgarh Kamdhenu Vishwavidhyalaya, Durg, Chhattisgarh, India. \\ Corresponding author: Priyanka Konwar, e-mail: priyankavet2009@gmail.com, SPT: drsptiwari@gmail.com, \\ MG: manujgohain02@gmail.com,KK: drkirankumari22@gmail.com \\ Received: 14-07-2015, Revised: 19-10-2015, Accepted: 23-10-2015, Published online: 24-11-2015
}

doi: 10.14202/vetworld.2015.1351-1355 How to cite this article: Konwar P, Tiwari SP, Gohain M, Kumari K (2015) The effects of protein dietary supplementation on fecal egg counts and hematological parameters in goat kids with subclinical nematodosis, Veterinary World 8(11): 1351-1355.

\begin{abstract}
Aim: The aim of the present study was to assess the effect of dietary supplementation with different levels of protein on fecal egg counts and hematological parameters in goat kids with subclinical nematodosis under semi-intensive condition.

Materials and Methods: 20 goat kids (3-5 months old with an average body weight of $8.90 \mathrm{~kg}$ ) were randomly allocated to four groups: T1, served as a negative control, without receiving concentrate feed, and T2, T3, and T4 that received concentrate feed containing 16, 20, and $24 \%$ digestible crude protein, respectively. The experiment was carried out for 60 days.

Results: In this study, protein supplementation had a significant $(\mathrm{p}<0.05)$ effect on fecal egg counts even after 15 days; hemoglobin $(\mathrm{Hb})(\mathrm{g} / \mathrm{dl})$ after 45 days; total leukocyte count $\left(10^{3} / \mathrm{mm}^{3}\right)$ and total erythrocyte count $\left(10^{6} / \mathrm{mm}^{3}\right)$ after 30 days; packed cell volume (\%), lymphocyte (\%), and eosinophil (\%) after 15 days of supplementation, whereas monocyte (\%) and neutrophil (\%) values were not significantly influenced by protein supplementation effect during the entire experiment. The values of mean corpuscular volume (fl) were affected significantly $(\mathrm{p}<0.05, \mathrm{p}<0.01)$ due to protein supplementation after 30 days, mean corpuscular $\mathrm{Hb}(\mathrm{MCH})(\mathrm{pg})$ after 45 days, but $\mathrm{MCH}$ concentration (g/dl) was not significantly different among the experimental groups during the entire experiment.
\end{abstract}

Conclusion: The dietary supplementation with different levels of protein significantly improved the hematological profiles and inhibited the nematodosis infection in the experimental goat kids.

Keywords: fecal egg count, goat kids, hematological parameter, nematodosis, protein dietary supplementation.

\section{Introduction}

Gastrointestinal parasitism is a major problem in a small ruminant production worldwide, due to its impact on animal health and productivity and the associated costs of control measures [1]. The usual strategy of gastrointestinal nematodes control based on the repeated use of anthelmintics and is nowadays under question because of the increasing development of resistance to these molecules [2].

The manipulation of host nutrition is the alternative method to anthelmintics and is intended to improve the host resistance and/or resilience against parasitic infections. Research has already shown that increased dietary intake of metabolizable protein and energy and combined with high-quality pasture can directly promote the host resistance and resilience against worm infection by maintaining tissue and/or blood homeostasis and production $[3,4]$. An improvement of the host diet contributes to maintain the tissue and/or blood homeostasis and the host production despite the presence of worms.

The present study was, therefore, carried out to study the effect of protein dietary supplementation on

Copyright: The authors. This article is an open access article licensed under the terms of the Creative Commons Attributin License (http:// creative commons.org/licenses/by/2.0) which permits unrestricted use, distribution and reproduction in any medium, provided the work is properly cited.
Egg per gram (EPG of feces) and different hematological parameters in goat kids infected with natural subclinical nematodosis.

\section{Materials and Methods}

Ethical approval

Permission of the Institutional Animal Ethics Committee was taken prior to the start of the experiment.

Experimental animal, diet, design, and management 20 indigenous goat kids of $3-5$ months old infected by natural subclinical nematodosis were selected for the experiment conducted in the Department of Animal Nutrition, College of Veterinary Science and Animal Husbandry, Anjora, Durg (Chhattisgarh) and randomly allocated to four groups of five animals each ( $\mathrm{T} 1$ served as a negative control, without receiving concentrate feed, and T2, T3, and T4 that received concentrate feed containing $16 \%, 20 \%$, and $24 \%$ digestible crude protein [DCP], respectively). They were ear tagged for identification and experiment was carried out for 60 days with the completely randomized design under semi-intensive condition. Animals were individually fed and were reared under same conditions of hygiene and management.

The animals grazed in a pasture containing mixed grass predominant with sola grass (Aeschynomene indica) for $4 \mathrm{~h}$ ( 8 am to 12 noon) and concentrate feed 
$(100 \mathrm{~g} /$ day/animal) was offered at 3:30 pm. Fecal egg count was were determined to confirm the occurrence of nematodosis. Diets were formed by using crushed maize, soybean meal, de-oiled rice bran; in detail, T2, $\mathrm{T} 3$, and T4 diets contained $70 \%$ of total digestible nutrients and $16 \%, 20 \%$ and $24 \%$ of DCP, respectively. The diets were further supplemented with mineral mixture $(2 \%)$ and salt $(1 \%)$. The diets were formulated as per standard requirement [5].

\section{Blood and fecal sample collection}

The fresh fecal samples from all kids were individually collected using hand gloves at $0,15,30$, 45 , and 60 days. The samples were put in the plastic bags for egg counting as described by the modified McMaster techniques [6]. Blood samples were also collected from all kids at $0,15,30,45$ and 60 days. In detail, $2 \mathrm{ml}$ blood was taken in a glass vial containing ethylene diamine tetra acetate appropriate for hematological analyses. Immediately after blood collection, the tubes were gently rotated between palms to mix it with anticoagulant. Hemoglobin $(\mathrm{Hb})$, packed cell volume (PCV), total erythrocyte count (TEC), total lymphocyte count (TLC), differential leukocyte count - monocyte, lymphocyte, neutrophil and eosinophil, mean corpuscular volume (MCV), mean corpuscular $\mathrm{Hb}(\mathrm{MCH})$, and $\mathrm{MCH}$ concentration $(\mathrm{MCHC})$ were performed as described by Jain [7].

\section{Statistical analysis}

The results obtained during this study were analyzed by as per Snedecor and Cochran [8] using software package SPSS version 16.0 [9].

\section{Results and Discussion}

\section{EPG}

The mean values of EPG (Table-1) significantly differ $(\mathrm{p}<0.05)$ among the treatments. The highest values were obtained in $\mathrm{T} 1$ and lowest in $\mathrm{T} 3$ and T4, even from the first 15 days of protein dietary supplementation. The values were increased throughout the experiment possibly due to flock grazing. Especially, T3 have significantly $(\mathrm{p}<0.01)$ lower values than $\mathrm{T} 1$ and $\mathrm{T} 2$ groups suggesting that the supplementation influenced the rate of larval development in the kids. It might also be an effect of resistance and/or resilience increase against nematodes due to higher protein supplementation level. Previous studies have also revealed that there is a significant reduction in the fecal egg count and worm burden in goats after supplementation with dietary protein $[10,11]$.

\section{Percentile depiction of nematode genera}

From the pooled coproculture, the infective larvae were harvested, and it was observed that predominantly Haemonchus sp. were present in all the treatments at a ratio of 9:1.

\section{Hematological profiles}

The $\mathrm{Hb}$ concentration significantly differed $(p<0.01)$ amongst the different groups at $45^{\text {th }}$ and $60^{\text {th }}$ day of the experiment (Table-2). The concentration at the $45^{\text {th }}$ day was higher in protein supplemented groups and at the $60^{\text {th }}$ day, values were the highest in $\mathrm{T} 3$ and $\mathrm{T} 4$. The concentration of $\mathrm{Hb}$ decreased as the levels of infection and incubation period increased. However as the level of protein supplementation increased, the $\mathrm{Hb}$ content also increased after the $30^{\text {th }}$ day of the experiment, especially after the $45^{\text {th }}$ day. In the present study, a reduction in $\mathrm{Hb}$ content was observed, possibly as a result of either blood loss due to blood-sucking by larvae and adults [12] or due to mucosa damage [13]. Al-Rekani [14] revealed that there is significant reduction in $\mathrm{Hb}$ in infected goats compared to control. With increase in parasitemia rates, $\mathrm{Hb}$ concentration significantly decreased in small ruminants naturally infected with parasites [15]. Parasitic anemia is related with low Hb levels, eosinophilia and a moderate lymphopenia in naturally infected sheep [16]. Abdel Hameed et al. [17] reported higher values of $\mathrm{Hb}$ in diets with a higher level of protein supplementation in Sudan desert lambs compared to other experimental diets.

The mean TLC values significantly differed among the experimental groups on day $30(\mathrm{p}<0.05)$ and on days 45 and $60(\mathrm{p}<0.01)$ of the experiment; in general, T3 and T4 had higher values compared to T1 and T2 group (Table-2). TLC value increased as the levels of infection and incubation period increased, possibly as a result of parasitic infection. Qamar [18] reported that TLC values were significantly affected by the extent of nematode parasitosis. In the case of parasitized animals that are supplemented with proteins, the number of eosinophils and other leukocytes, mast cells and proteases released from the mast cells increased in the mucosa of the gastrointestinal tract [19]. TLC showed a significantly increased value in small ruminants naturally infected with parasites [15].

Table-1: The effect of protein supplementation on fecal egg count in goats.

\begin{tabular}{|c|c|c|c|c|c|c|}
\hline \multirow[t]{2}{*}{ Parameters } & \multirow{2}{*}{$\begin{array}{l}\text { Period } \\
\text { (day) }\end{array}$} & \multicolumn{4}{|c|}{ Treatments } & \multirow[t]{2}{*}{ Significance } \\
\hline & & T1 & T2 & T3 & T4 & \\
\hline \multirow[t]{5}{*}{ EPG } & 0 & $1520 \pm 73.48$ & $1480 \pm 73.48$ & $1520 \pm 37.42$ & $1500 \pm 70.71$ & NS \\
\hline & 15 & $1860 \pm 50.99^{b}$ & $1720 \pm 58.31^{a b}$ & $1680 \pm 37.42^{a}$ & $1620 \pm 73.48^{a}$ & $*$ \\
\hline & 30 & $2240 \pm 67.82^{b}$ & $1920 \pm 58.31^{a}$ & $1820 \pm 37.42^{\mathrm{a}}$ & $1840 \pm 81.24^{a}$ & $* *$ \\
\hline & 45 & $2580 \pm 48.99^{b}$ & $2080 \pm 58.31^{\mathrm{a}}$ & $1920 \pm 37.42^{\mathrm{a}}$ & $2020 \pm 96.95^{a}$ & $* *$ \\
\hline & 60 & $2920 \pm 58.31^{c}$ & $2320 \pm 58.31^{b}$ & $2040 \pm 50.99^{a}$ & $2220 \pm 86.02^{\mathrm{ab}}$ & $* *$ \\
\hline
\end{tabular}

abcMeans within a row with different superscripts are significantly different $(* p<0.05, * * p<0.01)$. NS=Not significant 
The mean values of TEC significantly differed $(p<0.05, p<0.01)$ among the experimental groups during the experiment apart from the day 0 to 15 (Table-2). Lower values were shown in T1 than the other treatments. Decreased level of TEC as a result of increase in parasitemia were reported in small ruminants with natural parasitic infestation $[14,15]$. Abdel Hameed et al. [17] reported higher TEC values in diets supplemented with different level of protein in Sudan desert lambs compared to other experimental diets.

The mean PCV values significantly differed $(p<0.01)$ among the experimental groups during the entire period apart from day 0 (Table-2). On day 30,45 , and $60, \mathrm{~T} 3$ showed the highest and $\mathrm{T} 11^{\text {the }}$ lowest values compared to T2 and T4 group, possibly as a result of the improved nutrition of the parasitized animals. The higher dietary protein improved the erythropoiesis or reduced the establishment or development of adult nematodes. The kids on the higher protein diet even with heavy infection better able to resist the adverse effect of gastrointestinal nematodosis. Al-Rekani [14], Esmaeilnejad [15] also reported decreased values of PCV in infected compared to control animals.

The influence of protein supplementation level on monocyte and neutrophil values are also presented in Table-3. No significant differences were found among the treatments. The values of monocytes did not follow any specific trend and in the case of neutrophil; there was a decreasing but not significant trend in $\mathrm{T} 2, \mathrm{~T} 3$, and T4. Esmaeilnejad et al. [15] reported that neutrophil counts were significantly increased with the increase of parasitemia rates in natural parasitic small ruminants, a finding that is in accordance with the present study.

The influence of protein supplementation on lymphocyte count in kids was significant $(p<0.01)$ from the $15^{\text {th }}$ day (Table- 3 ). The highest values were constantly showed by $\mathrm{T} 1$ and lowest by $\mathrm{T} 3$ group. The results of the present study might be due to the chronic infection of nematodosis resulting in the exhausted immune system. Esmaeilnejad et al. [15] reported that number of lymphocyte increased significantly in natural parasitic small ruminants which were in accordance with the present findings.

As presented in Table-3, eosinophil count was significantly influenced by protein supplementation apart from day 0 . The eosinophil count was higher in T1 followed by T2, T4 and T3. It has already been suggested that eosinophil count may provide an index of protective immune response of animals to parasitism [20]. With increase in parasitemia rates, eosinophil count shows a significantly increased value in small ruminants with natural parasitic infection [15].

The average values of $\mathrm{MCV}, \mathrm{MCH}$, and $\mathrm{MCHC}$ of the experimental groups are presented in Table- 4 . The MCV values were higher in T3 and T4 compared to other groups on days 30,45 and 60 . The MCH values were higher in $\mathrm{T} 3$ and $\mathrm{T} 4$ compared to $\mathrm{T} 1$ group on days 45 and 60. No significant differences in MCHC values were found among the groups. However, the values were decreased as the time period and level of infection increased. The present findings of MCV and $\mathrm{MCH}$ were supported by previous studies in goats infected with parasites [15]. However, in contrast with the present study, MCV appeared to slightly increase with increase in worm load in cattle affected by fascioliasis [21]. Abdel Hameed et al. [17] also reported higher values in diets with different level of protein supplementation in Sudan desert lambs compared to other experimental diets which were in accordance with present findings. MCHC showed no reasonable

Table-2: The effect of protein supplementation on hematological parameters in goats.

\begin{tabular}{|c|c|c|c|c|c|c|}
\hline \multirow[t]{2}{*}{ Parameters } & \multirow{2}{*}{$\begin{array}{l}\text { Period } \\
\text { (days) }\end{array}$} & \multicolumn{4}{|c|}{ Treatments } & \multirow[t]{2}{*}{ Significance } \\
\hline & & $\mathbf{T 1}$ & T2 & T3 & T4 & \\
\hline \multirow[t]{5}{*}{$\mathrm{Hb}(\mathrm{g} / \mathrm{dl})$} & 0 & $12.58 \pm 0.63$ & $11.28 \pm 0.31$ & $11.32 \pm 0.27$ & $11.44 \pm 0.27$ & NS \\
\hline & 15 & $10.56 \pm 0.70$ & $10.38 \pm 0.33$ & $10.46 \pm 0.20$ & $10.64 \pm 0.27$ & NS \\
\hline & 30 & $8.82 \pm 0.49$ & $9.36 \pm 0.26$ & $9.80 \pm 0.19$ & $9.88 \pm 0.26$ & NS \\
\hline & 45 & $7.08 \pm 0.39^{a}$ & $8.52 \pm 0.38^{b}$ & $9.24 \pm 0.17^{b}$ & $9.10 \pm 0.23^{b}$ & $* *$ \\
\hline & 60 & $5.72 \pm 0.25^{a}$ & $7.18 \pm 0.27^{b}$ & $8.66 \pm 0.16^{c}$ & $8.30 \pm 0.26^{c}$ & $* *$ \\
\hline \multirow[t]{5}{*}{$\operatorname{TLC}\left(10^{3} / \mathrm{mm}^{3}\right)$} & 0 & $7.14 \pm 0.11$ & $7.17 \pm 0.16$ & $7.18 \pm 0.11$ & $7.27 \pm 0.16$ & NS \\
\hline & 15 & $7.25 \pm 0.12$ & $7.37 \pm 0.17$ & $7.56 \pm 0.12$ & $7.59 \pm 0.17$ & NS \\
\hline & 30 & $7.39 \pm 0.09^{a}$ & $7.61 \pm 0.17^{a b}$ & $7.98 \pm 0.12^{\mathrm{b}}$ & $7.92 \pm 0.16^{b}$ & $*$ \\
\hline & 45 & $7.51 \pm 0.07^{a}$ & $7.83 \pm 0.18^{\mathrm{ab}}$ & $8.39 \pm 0.12^{c}$ & $8.22 \pm 0.16^{b c}$ & $* *$ \\
\hline & 60 & $7.65 \pm 0.06^{a}$ & $8.03 \pm 0.19^{a}$ & $8.80 \pm 0.12^{\mathrm{b}}$ & $8.51 \pm 0.15^{b}$ & $* *$ \\
\hline \multirow[t]{5}{*}{ TEC $\left(10^{6} / \mathrm{mm}^{3}\right)$} & 0 & $12.34 \pm 0.14$ & $12.48 \pm 0.18$ & $12.36 \pm 0.15$ & $12.42 \pm 0.19$ & NS \\
\hline & 15 & $11.71 \pm 0.15$ & $12.04 \pm 0.18$ & $12.09 \pm 0.14$ & $12.06 \pm 0.20$ & NS \\
\hline & 30 & $11.04 \pm 0.16^{a}$ & $11.58 \pm 0.18^{b}$ & $11.74 \pm 0.19^{b}$ & $11.66 \pm 0.19^{b}$ & $*$ \\
\hline & 45 & $10.35 \pm 0.15^{a}$ & $11.08 \pm 0.17^{b}$ & $11.49 \pm 0.12^{\mathrm{b}}$ & $11.26 \pm 0.20^{\mathrm{b}}$ & $* *$ \\
\hline & 60 & $9.65 \pm 0.16^{\mathrm{a}}$ & $10.56 \pm 0.19^{b}$ & $11.19 \pm 0.14^{c}$ & $10.85 \pm 0.20^{\mathrm{bc}}$ & $* *$ \\
\hline \multirow[t]{5}{*}{ PCV (\%) } & 0 & $33.26 \pm 0.35$ & $32.74 \pm 0.30$ & $32.92 \pm 0.40$ & $32.66 \pm 0.38$ & NS \\
\hline & 15 & $29.38 \pm 0.66^{a}$ & $29.86 \pm 0.21^{a}$ & $31.90 \pm 0.35^{b}$ & $30.42 \pm 0.47^{a b}$ & $* *$ \\
\hline & 30 & $25.52 \pm 0.71^{a}$ & $26.68 \pm 0.26^{\mathrm{ab}}$ & $30.58 \pm 0.35^{c}$ & $28.40 \pm 0.44^{b}$ & $* *$ \\
\hline & 45 & $21.48 \pm 0.74^{a}$ & $23.58 \pm 0.23^{b}$ & $29.04 \pm 0.31^{d}$ & $26.70 \pm 0.44^{c}$ & $* *$ \\
\hline & 60 & $17.88 \pm 0.76^{a}$ & $20.02 \pm 0.37^{b}$ & $27.52 \pm 0.21^{d}$ & $24.26 \pm 0.46^{c}$ & $* *$ \\
\hline
\end{tabular}

abcMeans within a row with different superscripts are significantly different $(* p<0.05, * * p<0.01)$. Hb=Hemoglobin, $\mathrm{PCV}=$ Packed cell volume, TEC=Total erythrocyte count, TLC=Total leukocyte count, NS=Not significant 
Table-3: The effect of protein supplementation on DLCs in goats.

\begin{tabular}{|c|c|c|c|c|c|c|}
\hline \multirow[t]{2}{*}{ Parameters } & \multirow{2}{*}{$\begin{array}{l}\text { Period } \\
\text { (days) }\end{array}$} & \multicolumn{4}{|c|}{ Treatments } & \multirow[t]{2}{*}{ Significance } \\
\hline & & T1 & $\mathbf{T 2}$ & T3 & T4 & \\
\hline \multirow[t]{5}{*}{ Monocytes (\%) } & 0 & $1.60 \pm 0.75$ & $1.80 \pm 0.80$ & $1.40 \pm 0.98$ & $1.40 \pm 0.98$ & NS \\
\hline & 15 & $1.40 \pm 0.60$ & $1.40 \pm 0.98$ & $1.40 \pm 0.87$ & $1.20 \pm 0.97$ & NS \\
\hline & 30 & $1.60 \pm 0.81$ & $1.20 \pm 0.97$ & $1.40 \pm 1.40$ & $1.40 \pm 0.98$ & NS \\
\hline & 45 & $1.20 \pm 0.73$ & $1.20 \pm 1.20$ & $1.60 \pm 1.03$ & $1.60 \pm 1.17$ & NS \\
\hline & 60 & $2.00 \pm 0.89$ & $1.20 \pm 0.97$ & $1.40 \pm 1.40$ & $1.40 \pm 1.17$ & NS \\
\hline \multirow[t]{5}{*}{ Lymphocytes (\%) } & 0 & $51.60 \pm 0.93$ & $51.40 \pm 0.93$ & $51.60 \pm 1.03$ & $51.60 \pm 0.75$ & NS \\
\hline & 15 & $50.80 \pm 0.80^{d}$ & $48.00 \pm 0.55^{c}$ & $44.40 \pm 0.60^{a}$ & $46.20 \pm 0.37^{b}$ & $* *$ \\
\hline & 30 & $48.80 \pm 0.37^{d}$ & $46.20 \pm 0.37^{c}$ & $42.00 \pm 0.45^{a}$ & $44.20 \pm 0.37^{b}$ & $* *$ \\
\hline & 45 & $45.80 \pm 0.58^{d}$ & $44.20 \pm 0.37^{c}$ & $40.20 \pm 0.37^{a}$ & $42.00 \pm 0.32^{b}$ & $* *$ \\
\hline & 60 & $43.20 \pm 0.58^{c}$ & $42.20 \pm 0.37^{c}$ & $38.20 \pm 0.37^{a}$ & $39.80 \pm 0.37^{b}$ & $* *$ \\
\hline \multirow[t]{5}{*}{ Neutrophils (\%) } & 0 & $41.80 \pm 0.80$ & $42.00 \pm 0.55$ & $41.80 \pm 0.80$ & $41.60 \pm 0.75$ & NS \\
\hline & 15 & $42.00 \pm 0.84$ & $41.00 \pm 0.89$ & $41.00 \pm 1.05$ & $41.00 \pm 0.89$ & NS \\
\hline & 30 & $42.00 \pm 0.84$ & $40.00 \pm 0.71$ & $40.40 \pm 0.75$ & $40.20 \pm 0.66$ & NS \\
\hline & 45 & $42.20 \pm 1.02$ & $39.00 \pm 0.89$ & $39.80 \pm 1.07$ & $39.40 \pm 0.93$ & NS \\
\hline & 60 & $42.20 \pm 1.02$ & $38.40 \pm 0.93$ & $39.40 \pm 0.93$ & $38.60 \pm 0.81$ & NS \\
\hline \multirow[t]{5}{*}{ Eosinophils (\%) } & 0 & $5.20 \pm 0.37$ & $5.40 \pm 0.24$ & $5.00 \pm 0.32$ & $5.20 \pm 0.20$ & NS \\
\hline & 15 & $9.20 \pm 0.37^{b}$ & $8.40 \pm 0.24^{b}$ & $7.00 \pm 0.32^{\mathrm{a}}$ & $7.40 \pm 0.24^{a}$ & $* *$ \\
\hline & 30 & $13.20 \pm 0.37^{d}$ & $11.40 \pm 0.24^{c}$ & $8.20 \pm 0.37^{a}$ & $9.40 \pm 0.24^{b}$ & $* *$ \\
\hline & 45 & $16.20 \pm 0.37^{d}$ & $13.80 \pm 0.49^{c}$ & $9.40 \pm 0.24^{a}$ & $11.40 \pm 0.24^{b}$ & $* *$ \\
\hline & 60 & $19.20 \pm 0.37^{d}$ & $16.40 \pm 0.24^{c}$ & $10.80 \pm 0.20^{a}$ & $13.60 \pm 0.24^{b}$ & $* *$ \\
\hline
\end{tabular}

abcMeans within a row with different superscripts are significantly different $(* * p<0.01)$. NS=Not significant, DLC=Differential leukocyte count

Table-4: The effect of protein supplementation on red blood cell indices in goats.

\begin{tabular}{|c|c|c|c|c|c|c|}
\hline \multirow[t]{2}{*}{ Parameters } & \multirow{2}{*}{$\begin{array}{l}\text { Period } \\
\text { (days) }\end{array}$} & \multicolumn{4}{|c|}{ Treatments } & \multirow[t]{2}{*}{ Significance } \\
\hline & & T1 & T2 & T3 & T4 & \\
\hline \multirow[t]{5}{*}{$\operatorname{MCV}(\mathrm{fl})$} & 0 & $26.96 \pm 0.29$ & $26.24 \pm 0.28$ & $26.64 \pm 0.55$ & $26.31 \pm 0.57$ & NS \\
\hline & 15 & $25.08 \pm 0.53$ & $24.81 \pm 0.29$ & $26.38 \pm 0.47$ & $25.25 \pm 0.68$ & NS \\
\hline & 30 & $23.12 \pm 0.59^{a}$ & $23.04 \pm 0.27^{a}$ & $26.08 \pm 0.69^{b}$ & $24.39 \pm 0.64^{\mathrm{ab}}$ & $* *$ \\
\hline & 45 & $20.76 \pm 0.64^{a}$ & $21.29 \pm 0.43^{a}$ & $25.28 \pm 0.47^{b}$ & $23.72 \pm 0.61^{b}$ & $* *$ \\
\hline & 60 & $18.51 \pm 0.67^{a}$ & $18.98 \pm 0.56^{a}$ & $24.61 \pm 0.41^{c}$ & $22.38 \pm 0.62^{b}$ & $* *$ \\
\hline \multirow[t]{5}{*}{$\mathrm{MCH}(\mathrm{pg})$} & 0 & $10.21 \pm 0.57$ & $9.05 \pm 0.30$ & $9.17 \pm 0.32$ & $9.23 \pm 0.27$ & NS \\
\hline & 15 & $9.03 \pm 0.63$ & $8.63 \pm 0.31$ & $8.65 \pm 0.23$ & $8.83 \pm 0.28$ & NS \\
\hline & 30 & $8.00 \pm 0.46$ & $8.09 \pm 0.25$ & $8.35 \pm 0.24$ & $8.48 \pm 0.28$ & NS \\
\hline & 45 & $6.85 \pm 0.39^{a}$ & $7.70 \pm 0.38^{\mathrm{ab}}$ & $8.04 \pm 0.20^{b}$ & $8.09 \pm 0.27^{b}$ & $*$ \\
\hline & 60 & $5.94 \pm 0.35^{a}$ & $6.81 \pm 0.32^{\mathrm{ab}}$ & $7.75 \pm 0.21^{b}$ & $7.66 \pm 0.29^{b}$ & $* *$ \\
\hline \multirow[t]{5}{*}{ MCHC (g/dl) } & 0 & $37.83 \pm 1.89$ & $34.47 \pm 1.04$ & $34.40 \pm 0.86$ & $35.03 \pm 0.78$ & NS \\
\hline & 15 & $35.93 \pm 2.16$ & $34.76 \pm 1.07$ & $32.80 \pm 0.65$ & $34.98 \pm 0.70$ & NS \\
\hline & 30 & $34.55 \pm 1.58$ & $35.09 \pm 1.01$ & $32.06 \pm 0.75$ & $34.79 \pm 0.84$ & NS \\
\hline & 45 & $33.00 \pm 1.60$ & $36.09 \pm 1.33$ & $31.84 \pm 0.75$ & $34.12 \pm 1.04$ & NS \\
\hline & 60 & $32.30 \pm 2.34$ & $35.82 \pm 0.75$ & $31.48 \pm 0.76$ & $34.27 \pm 1.33$ & NS \\
\hline
\end{tabular}

abcMeans within a row with different superscripts are significantly different $(* p<0.05, * * p<0.01)$. NS=Not significant, $\mathrm{MCV}=$ Mean corpuscular volume, $\mathrm{MCH}=$ Mean corpuscular hemoglobin, $\mathrm{MCHC}=$ Mean cell hemoglobin concentration

change with increase in worm load in cattle affected with fascioliasis [21]. Reduced level of MCHC with the increase in infection was also observed in small ruminants with natural parasitic infection [15]. At the same time, higher values of MCHC were recorded in diets with different level of protein supplementation in Sudan desert lambs compared to other experimental diets [17].

\section{Conclusion}

It may be concluded that dietary supplementation with different levels of protein in goats with subclinical nematodosis had significant beneficial effects on reducing the worm egg count and on improving hematological profile with respect to $\mathrm{Hb}$, TLC, TEC, PCV, lymphocyte, eosinophil, MCV, and
$\mathrm{MCH}$. Thus, protein-rich concentrate feed may be used as part of a sustainable strategy to control gastrointestinal nematodosis in goat kids under semi-intensive conditions.

\section{Authors' Contributions}

PK carried out the experiment. SPT - Designed and guided the experiment. MG and KK help in sample processing and data analysis. All authors read and approved the final manuscript.

\section{Acknowledgments}

The authors are thankful to the Dean, College of Veterinary Science and Animal Husbandry, Anjora, Durg for providing necessary fund and facilities required to accomplish the experiment. 


\section{Competing Interests} interests

The authors declare that they have no competing

\section{References}

1. Knox, M.R., Torres-Acosta, J.F.J. and AguilarCaballero, A.J., (2006) Exploiting the effect of dietary supplementation of small ruminants on resilience and resistance against gastrointestinal nematodes. Vet. Parasitol., 139: 385-393

2. Sanyal, P.K. (1998) Integrated parasite management in ruminants in India. A concept note. Biological control of gastrointestinal parasites in ruminants using predacious fungi. FAO Animal Production \& Health Paper 141. FAO, Rome. p54-65.

3. Knox, M.R. (2002) Effectiveness of copper oxide wire particles for Haemonchus contortus control in sheep. Aust. Vet. J., 80: 224-227.

4. Pathak, A.K. and Tiwari, S.P. (2013) Effect of high plane of nutrition on the performance of Haemonchus contortus infected kids. Vet. World, 6(1): 22-26.

5. National Research Council. (1981) Nutrient Requirements of Domestic Animals; Nutrient Requirement of Goats. No. 15 National Academy Press, Washington, DC.

6. Skerman, K.D. and Hillard, J.J. (1966) A Handbook of Studies of Helminth Parasites of Ruminants. Near East Animal Health Institute, Iran, FAO, Rome.

7. Jain, N.C. (1986) Haematological techniques. In: Schalm's Veterinary Haematology. $4^{\text {th }}$ ed. Lea and Febinger, Philadelphia, PA. p20-86.

8. Snedecor, G.W. and Cochran, W.B. (1994) Statistical Methods. $8^{\text {th }}$ ed. Iowa State University Press, Ames, Iowa.

9. SPSS. (2010) Statistical Packages for Social Sciences. Version 16, SPSS Inc., Illinois, USA.

10. Mhomga, L.I., Nnadi, P.A., Chiejina, S.N., Idika, I.K. and Ngongeh, L.A. (2012) Effect of protein supplementation on weight gain and dressing percentage of West African Dwarf goats experimentally infected with Haemonchus contortus and Trichostrongylus colubriformis. Glob. Adv. Res. J. Agric. Sci., 1: 279-287.
11. Houdijk, J.G.M. (2012) Differential effects of protein and energy scarcity on resistance to nematode parasites. Small Rumin. Res., 103: 41-49.

12. Rowe, J.B., Nolan, J.V., Dechaneet, G. and Telani, F. (1988) The effect of haemonchosis and blood loss into the abomasums on digestion in sheep. Br. J. Nutr., 59: 125-139.

13. Abbott, E.M., Parkins, J.J. and Holmes, P.H. (1988) Influence of dietary protein on the pathophysiology of haemonchosis in lambs given continuous infections. Res. Vet. Sci., 45: 41-49.

14. Al-Rekani, A.M.A. (2012) Effect of natural infection with gastrointestinal nematode on milk composition and blood parameters of lactating native goats. Int. J. Sci. Res., 1(2): 14-17.

15. Esmaeilnejad, B., Tavassoli, M. and Asri-Rezaei, S. (2012) Investigation of hematological and biochemical parameters in small ruminants naturally infected with Babesia ovis. Vet. Res. Forum, 3: 31-36.

16. Yuksek, N., Altug, N., Denizhan, V., Ceylan, E. and Agaoglu, Z. (2013) Enhancement of the glucose metabolism and the reverse cholesterol transport by a peroxisome proliferator receptor $\alpha$ (PPARa) agonist included in the fasciolosis treatment in naturally infested sheep. Rev. Med. Vet. Toulouse, 164: 163-172.

17. Abdel Hameed, A.A., Salih, A.M., Fadel Elseed, A.M. and Amasab, E.O. (2013) Effect of feeding untreated or urea treated groundnut hull supplemented with different protein sources on blood parameters of Sudan desert lambs. Online J. Anim. Feed Res., 3: 40-46.

18. Qamar, M.F. (2009) Epidemiology, serodiagnosis, economic lossses and control of haemonchosis in sheep and goat. Ph.D. Thesis. Department of Parasitology. University of Veterinary and Animal Sciences Lahore, Pakistan.

19. Basabe, J., Eiras, D.F. and Romero, J.R. (2009) Nutrition and gastrointestinal parasitism in ruminant production. Arch. Zootec., 58: 131-144.

20. Finkelman, F.D., Pearce, E.J., Urban, J.F. and Sher, A. (1991) Regulation and biological function of helminth-induced cytokine responses. Immunol. Today, 12: A62-A66.

21. Egbu, F.M.I., Patience, O.U. and Ikem, C.O. (2013) Haematological changes due to bovine fascioliasis. Afr. J. Biotechnol., 12: 1828-1835. 